WIENER SLAVISTISCHES JAHRBUCH, Band 52/2006, 105-112

(C) 2007 by Österreichische Akademie der Wissenschaften, Wien

PETR NEJEDLÝ

\title{
Vývoj lexikální jednotky v (ne-)spisovném českém jazyce (na prííkladu germanismu rajčúl, rajčúr) ${ }^{1}$
}

(1) Lexikální jednotky vázané téměř výhradně na mluvený jazyk donedávna přežívaly na okraji pozornosti lexikologů. Důvodem nebyl nedostatek badatelského zájmu, ale malá dostupnost jazykového materiálu, protože pro masivnější záznam a rozbor mluveného jazyka nebyly dostatečné technické prostředky a protože $\mathrm{v}$ písemném jazyce se tyto jednotky téměř nevyskytovaly, nanejvýš se zř́́dka užily jako ozvláštňující jazykový prvek, který střídmě ilustruje popisované prostředí, postavu, komunikační situaci apod. ${ }^{2}$

(2) Situace se výrazně změnila nástupem technicky výtečně vybavené korpusové a komputační lingvistiky a vstupem primární písemné formy do textů výsostně soukromých (přesněji tváŕících se tak) a opřených o mluvený jazyk, totiž s nástupem internetu a webových stránek. Tento komunikační prostor je naprosto otevřený a ve své strojové mechaničnosti, jakou pro uživatele představují třeba různé vyhledávače, staví na stejnou úroveň jakékoli texty a jakékoli vyjadřovací prostředky.

1 Příspěvek vznikl jako součást projektu Slovní zásoba češtiny doby střední - „editio princeps“ (analýza lexikálního materiálu a jeho zpř́istupnění v elektronické formě), řešeného v rámci podprogramu Národní politiky výzkumu I - Podpora projektů cíleného výzkumu (reg. č. 1QS900610505) a zároveň v rámci činnosti Výzkumného centra vývoje staré a střední češtiny (program MŠMT Centra základního výzkumu, reg. č. LC 546).

2 Jednotlivé lexikální jednotky užívané především v mluveném jazyce se tak trochu nespravedlivě ocitaly v pozici jakési jazykové kuriozity, a to i v případě jejich odborního zpracování - častěji bylo v rukou popularizátorů a poučených zájemců o jazyk než v rukou vlastních jazykovědců: př́ikladem budiž půvabná snůška Šmírbuch jazyka českého (Ouředník, P., Praha, Ivo Železný 1992; 2. vyd. Praha - Litomyšl, Paseka 2005) nebo zdánlivě ryze odborně pojatý Slovník nespisovné češtiny (Hugo, J. a kol., Praha, Maxdorf 2006), kde se najdou takové lexikografické lapsy, jako je psaní vixlajvand (německy Wichsleinwand) - přitom by bylo stačilo, kdyby byli sestavovatelé nahlédli do SSJČ. 
(3) Můžeme to ilustrovat na jednoduchém př́ikladu archaického expresiva rajčúr. Lexém není doložen v základních výkladových slovnících češtiny (s výjimkou Kottova, který uvádí z Policka podoby rajčúr, rajčúl s významem ,dřevěný koník * dostal krejcar na rajčúr ${ }^{3}$ - a bez vymezení významu podobu reitčur ${ }^{4}$ - zde Kott vyšel z textu písně, o níž viz níže). Je to pochopitelné: pro starší slovníky spisovného jazyka představoval tento lexém nepěkný a nekulturní germanismus, mladší slovníky (pokud jej vůbec excerpčně zachytily) jej musely hodnotit jako slovo řídké a beznadějně zastaralé, které neodpovídalo výběrovým kritériím daného slovníku ani možnostem jeho rozsahu. V podobě rajčur je proto lexém uveden již jen ve Slovníku nespisovné češtiny s nářečním významem , angrešt ${ }^{.}{ }^{5}$

(3.1) Zaznamenal jej však Machkův Etymologický slovník ${ }^{6}$ jako nářční výraz ve významu ,ochoz kolem žentouru'. Úplnější zpracování nabízí S. M. Newerkla: ${ }^{7}$ uvádí ještě další, vývojově sekundární význam ,nepořádek‘ ${ }^{\star} Z$ jeho údajů lze zrekonstruovat podstatnou část významového vývoje tohoto lexému (s variantami rajčur, rajčul): pochází z německého kompozita Reitschule ,jízdárna“ (české koncové $r$ je analogické náslovné souhlásce) a po přejetí do češtiny se stal polysémním: označoval jakýkoli ohraničený prostor charakteristický tím, že se v něm pohybují domácí zviŕata - v moravskoslezských nářečích měl význam ,ohrazená louka“ (na Slovensku dokonce ,ohrada, výběh pro prasata'). Přidáním dalších diferenčních sémantických rysů, omezením pojmenování na jedinou funkci pak vznikl Machkem uvedený význam, ochoz kolem žentouru'.

(3.2) Vedle apelativního užití máme $\mathrm{z}$ různých částí Čech doloženo pomístní jméno Rajčul(a)/Rajčur(a). ${ }^{8}$ Doloženo je v podobách $\operatorname{Rajčul}(a), \operatorname{Rajčur}(a), \operatorname{Raj}(t)$ čúl, Rajčúr(a), Rajtčúr, Rajtšul/Rajtšúl, Ratčur, Rejčur a dokonce Jarčúr a Drančur. ${ }^{9}$

${ }^{3}$ František Štefan Kott, Česko-německý slovník zvláště gramaticko-fraseologický, díl třetí $Q-\check{S}$, Praha 1882, s. 18. - Na téže straně Kott zaznamenal - tentokrát z Př́borska - odvozené sloveso rajtšulovati, prohnat, vytrestat, vycvičit‘.

${ }^{4}$ Op. cit. v pozn. 3., díl sedmý. II. dodatky $A-\check{Z}$, Praha 1893, s. 1375.

5 Op. cit. v pozn. 2., s. 290.

${ }^{6}$ Václav Machek, Etymologický slovník jazyka českého, Praha 1971, s. 506.

7 Stefan Michael Newerkla, Sprachkontakte Deutsch - Tschechisch - Slowakisch. Frankfurt am Main 2004, s. 337.

8 Viz Libuše Olivová-Nezbedová - Jana Matúšová, Index lexikálních jednotek pomístních jmen v Čechách, Praha 1991, s. 182.

9 V kartotéce onomastického oddělení Ústavu pro jazyk český Akademie věd České republiky je zaznamenán výklad, který ke jménu Drančúr (z Tmaně na Berounsku) podal místní informátor, že totiž na pozemku údajně drančily, tj. skotačily děti. Tento výklad nemá se skutečným významem pojmenování nic společného - jde o umělou, sekundární motivaci slovotvorně neprůhledného (a proto také zkomoleného) slova. 
Označují se jím pozemky (někdejší pole, louky, části lesa), které dříve sloužily jako cvičiště jízdního vojska.

(4) Ani Machek, ani Newerkla však nemají doklady na nadnářeční užití lexému ani na jeho užití v původním apelativním významu ,jízdárna‘. Takové doklady přinesla až excerpce humanistické a barokní češtiny pořízená Z. Tylem jako východisko pro zamýšlený slovník češtiny doby střední. Všechny čtyři doklady pocházejí z 18. století, z toho tři z nich z Pražských poštovských novin z 20. let 18. století (u prvního z nich nás nesmí mást užití počátečního velkého písmena - i tento výskyt považujeme za apelativum): (na památku zemřelé císařovny byla ve Vídni) na císařským Reitschulu jeden tisíc zlatých rejnských mezi obecné chudé almužna rozdává$n a ;{ }^{10}$ do svého císařského reythschulu prijeti (ráčil císař) ${ }^{11}$; při zdejším (tj. drážd'anském) královským dvoře ... masopustní veselosti posavade trvají. Dnešního dne a předvčirem královští dvořenínové průbu kolby k kroužku na zdejším reitschulu drželi. ${ }^{12}$

Poslední, mladší doklad pochází z 88. sloky písně o selském povstání roku 1775 zapsané písmákem Jiřím Paroubkem (1744 - 1824); doklad lexikograficky zpracoval již Kott (viz výše): jichž mnoho v Chlumci bylo schytáno, v zámku do rejtčuru vehnáno, tam několik dní bídnili, domů puštěni jsouc biti byli. ${ }^{13}$

(5) Ve světle těchto dokladů můžeme doplnit sémantický vývoj přeneseného substantiva rajčúl(a)/rajčúr(a) do následující vývojové linie: ,jízdárna‘ - ,vymezený pozemek sloužící jako cvičiště jezdectva“ - ,nářečně ,ohrazená louka - ohrazený pozemek pro domácí zvířata“- nářečně ,ochoz u žentouru‘. Poslední článek této vývojové sémantické řady ,nepořádek‘, uváděný Newerklou a vzniklý expresivním odstraněním všech nocionálních sémantických komponenti̊ z významu ,cvičiště‘, však zachycen stále nemáme (když si odmyslíme, že to je jediný význam tohoto lexému, který je od padesátých let 20. století znám autorovi tohoto článku jako součást aktivní slovní zásoby jeho prarodičủ ${ }^{14}$ ).

(6) Naše poznání se však dále mění zapojením elektronických médií, která netrpí nutností jakkoli šetřit rozsahem: alespoň jeden doklad jsme našli v materiálu Českého národního korpusu (korpus SYN 2005, stav z 31. července 2006): děsivý gong

\footnotetext{
${ }^{10}$ Pražské poštovské noviny 6. 2. 1720, s. 1

11 Pražské poštovské noviny 9. 11. 1720, s. 1.

12 Sobotní pražské poštovské noviny z 20. let 18. století, č. 27, viz: Č. Zíbrt, Cedule komediantů a zvěřinců kočujících v zemich českých, Český lid 21 (1912), s. 37.

13 Otakar G. Paroubek, Dvě písně o selském povstání r. 1775, Časopis Musea království Českého 67 (1893), s. 248-257.

14 Mezi příslušníky mladších generací působil už tehdy archaicky: k označení nepořádku pro ně byla běžnější jiná expresivní pojmenování (např. chliv(ek), svinčik, binec, čurbes, bordel aj.).
} 
$v$ duši. Hluboký dunivý gong. A potom: Glaú! Úplný rajčur. Samota - změtenostrozklad: Grach! Ahu! Nastává Padraikovo Nokturno. Utlačovatelé! Obludy! (Bohumil Nuska, Padraikův zánik, Torst, Praha 1997). Nepochybně zde máme lexikální jednotku s hledaným významem ,nepořádek‘.

(7) Ještě bohatší bylo $v$ tomto směru prohledávání webových stránek (provedené 26. července 2006). Poskytlo dlouhou řadu dokladů slova rajčúr (nebo jeho hláskových variant). ${ }^{15}$ Nejpočetněji - čtrnácti doklady - jsou zastoupena pomístní jména motivovaná, jak uvedeno výše, někdejším umístěním vojenského cvičiště (výjimkou je první doklad):

(7.1) Majitel panství komerčni rada Václav Palivec se každé ráno projižděl $v$ parku na koni, tedy rajtoval. Zřejmě od tohoto slova byl odvozen název rajčúr, který se ještě občas použivá (http://www.osov.cz/index2.php?page=ostatni - stránka obce Osov u Berouna); obecním pastvinám - drahám - u cesty doli do Švábenic na horním konci vsi se řikalo „Rajčůr" (http://www.sweb.cz/obec.horky/zpravodaj/ 200312.htm - stránka obce Horky u Litomyšle: Horecký zpravodaj, duben 2001 vzpomínky Marie Procházkové); Než však vznikla ves Kout, existovala na severním okraji obce (nyni Rajčůr) osada Brandýs (http://www.mujweb.cz/Spolecnost/Kout\% 2Dhistorie - stránka věnovaná obci Kout na Šumavě); Mezi kulturními zařizeními se uvádi výletiště Rajčur (http://www.mestolitovel.cz/doc/kultura.pdf - stránka města Litovle); Protože na pưvodním mistě stály konírny, nesl dům lidové pojmenování „,Reitschule“ (jizdárna), počeštěně „,Rajtšùl“, zlidovělý název „,Rajčur" (http:// mesta.obce.cz/vrane-nad-vltavou/zajimavosti.htm - stránka obce Vrané nad Vltavou); Jaroslav Kopáček (1906-1971), lidový hudebnik, skladatel a kapelník, od roku 1926 se pristěhoval do Vraného, pracoval jako dělník v mistni papirně, bydlel $v$ Rajčuru (http://www.mesta.obce.cz/vrane-nad-vltavou/osobnosti.htm - táž stránka Vraného nad Vltavou); $V$ jednom horkém létě se objevil na rajčůru ohromný barevný deštnik, vlastně slunečník (http://www.senio.cz/index.php?w=art\&id=1439 $\& \mathrm{rub}=4 \& \mathrm{~s}=-$ stránka nadace Senio: Antonín Mikolášek, Vzpomínky na slavné krajany); okrajem slatinského lesa $k$ Trejtnarově skalce a pobliž Borovinky [vede hranice obce]přes tzv. Rajčůru až nad silnici slatinskou (http://pecin.webzdarma.cz/ popis-obce.htm - stránka obce Pěčín); $V$ té době byly také postaveny dva muistky, umožňujici přistup $k$ chatám bratři Landkamrů [...] a k chatám „Na Rajčuru“ “ (http://stenovice.7data.cz/index.php?option=com_content\&task=view\&id=22\&Itemi d=79 - stránka obce Štěnovice: V. Laštovka, Z historie obce); od 14.00 turnaj v hliněnkách (Kravín - rajčůr) (http://www.unetice.cz/dokumenty/hl\%C3\%ADna\%20po

${ }^{15}$ Citáty jsou (s výjimkou nezbytného krácení vyznačeného hranatými závorkami) autentické, editovány jsou pouze evidentní písařské omyly a (naštěstí nečetné) křiklavé pravopisné (zvl. interpunkční) prohřešky (oddělování vět v souvětí, záměna číslovek základních a řadových atd.). 
zvanka\%203c.pdf - stránka obce Únětice); V neděli 16. ledna v 16.30 hod se společně sejdeme u ohně v Rajčưru (proluka mezi školkou a kravinem) (http://www.uneti ce.cz/ShowIt.asp?Page=Urad5\&ID=166 - táž stránka); Významnější polohy jílů se vytvořily na Rajčůru a pod kravínem, kde byly využivány pro výrobu veprovic [...] Začátkem první republiky bylo údajně založeno družstvo pro výstavbu cihelny, která měla využivat surovinu (jíly) na Rajčůru [...] Již v třicátých letech existovalo dalši sportovni hrišstě - Na Rajčuru (http://www.kozirynek.wz.cz/ujezd/ujezd.htm - stránka obce Újezd u Plánice na Klatovsku); přišlo nádherné počasí [...] Namisto sezení $u$ vody se ale konala druhá část brigády na sportovním stadionu „Na Rajčuru“ (http://kozirynek.wz.cz/zpravy.htm - stránka recesistického sdružení Kozí rynek z Újezdu u Plánice).

Kuriózní je v tomto směru webové zachycení primárního lingvistického textu: Dále jsou to pomistní jména přejatá z němčiny (např. U cechouzu, Na pančuli, Na rajčuru), která jsou důsledkem vnějši německé kolonizace, soužití Čechů s Němci, důsledkem vlivu specializovaných pracovniků nèmeckého původu (lesniků, horniků apod.), di̊sledkem vrchnostenských kancelárí úr̆adujicich německy (http://www. skaut.cz/kmen/stare/rocnik6/02_03_rocnik6_26.pdf - stránka skautského časopisu Roverský kmen 6, 2002, č. 26: přetisk článku Libuše Olivové-Nezbedové ${ }^{16}$ ).

(7.2) Třikrát je doložen také výchozí význam ,jízdárna': Kromě dosavadnich mrtvých se umiralo stále dál ve stavení, kde byli drženi pochytani rebelové, v panském rajčuru. Toto podivné slovo pochází z němčiny - pưvodně zde stály konírny a proto nesla budova lidové pojmenováni Reitschule - jizdárna, počeštěně rajtšůl, zlidověle rajčur [...] To byly čtyři oběti, které zemřely ve chlumecké jizdárně neboli v rajčuru (http://www.rozhlas.cz/praha/uslysime/_zprava/ 261632 - stránka Českého rozhlasu: Josef Veselý podle Petra Hory: Toulky českou minulostí - zpráva reaguje na tutéž událost jako výše uvedená Paroubkova píseň); Na památku po vojsku zbyly ruiny vyhořelých kasáren, jízdárna, zvaná lidově ,,rajčur" (z německého Reitschule), dnes je to parčík pred evangelickým kostelem (http://www.melnik.cz/upload_file /20030206141522_O_pocatcich_narodniho_obrozeni_Melnika.doc - stránka městského úřadu Mělník); spousta z těch německých výrazů se udržela i dlouho po převratu. Nečistilo se, ale pucovalo, ohlávky - to byly holstry, jizdárna byla rajčůr atd. Náš otec to nemohl ani cítit a netrpěl to doma ani ve službě (http://www.pardubice4 .cz/zpravodaj/2005_2.pdf - stránka městského úruadu Pardubice 4: Dr. Ladislav J. Haňka, Vzpomínky z Ameriky I. Hřebčinec v Nemošicích před 90 lety).

(7.3) V některých případech můžeme být na vážkách, zda máme co do činění s propriem, či s apelativem: Ve Staré Boleslavi vždy byla posádka dragounů a dělo-

16 Originál viz Libuše Olivová-Nezbedová, Pomístní jména jakožto svědectví o minulosti krajiny, v: Umělecká reflexe krajiny 4. Tvář naší země - krajina domova, Lomnice nad Popelkou 2001, 76-80. 
střelců. Na uvedené louce bylo cvičiště zvané Rajčur (http://www.gliding.cz/forum/ viewtopic.php?p=13448\&sid=17b02d30aa139fd6d4f93249a4a0ea06 - časopis o letectví Gliding - čtenářský ohlas).

(7.4) Kupodivu jsme dvakrát zaznamenali význam, který Newerkla ${ }^{17}$ uvádí jen pro slovenská nářečí - a to na území se Slovenskem nikterak nesousedícím: ${ }^{18}$ Jenom jsem sem nakoukla a Vaše diskuze mě zaujala [...] rajčur - výběh pro prasata (autorka: Marie z Pošumavi) (http://www.rodina.cz/scripts/diskuse/prisp.asp?id= 1107727 - internetový časopis Rodina - čtenářský prríspěvek k sbírce nářečních výrazů); výraz „rajčur “ na stejném teritoriu [tj. Putim] označuje „výběh pro prasata“ (http://slangy.cz/vase-prispevky/).

(7.5) Dva doklady označovaly Machkem uváděný význam ,ochoz u žentouru': název rajčůr, tj. plocha, na niž se žentour roztáčel (http://sweb.cz/obec.horky/ zpravodaj/200104.htm - stránka obce Horky u Litomyšle: Horecký zpravodaj, duben 2001 - Jan Morávek, Paměti); Žentour bylo prevodové litinové ústroji umistěné na rovné ploše, kterému se ř́kalo rajčur (http://www.sweb.cz/druhanov/zemed 19.htm - stránka obce Druhanov).

(7.6) V elektronické podobě se také objevuje slovník německých výpůjček v těšínských nářečích polštiny, ${ }^{19}$ který pod heslem rajczula vedle významů ,ohrazená pastvina‘, ,velký pokoj‘ a ,blátivá cesta“ uvádí jako srovnávací materiál i sousední moravské nářeční rajčula ,ohrazená pastvina‘ a Machkem zachycený rajčur ,ochoz kolem žentouru ${ }^{20}$ (http://www.uni-oldenburg.de/bkge/download/woerterbuch-te schenerdialekt/woerterbuch-r.pdf - stránka oldenburské univerzity). V komentáři autoři nadhazují možnost, že v př́ípadě pojmenování velké místnosti a špatně schůdné cesty slovem rajczula jde pouze o př́ležitostná užití. České významy ,pozemek (tj. velký prostor) ' a ,nepořádek' potvrzují, že tento významový posun je systémový a obecně platný, nemusí se proto jednat o okazionalismy.

Vedle toho autoři připomínají, že slezská němčina uživá substantivum Reitschule ve významech ,kolotoč ‘ a ,postel' a kladou si otázku, zda bylo slovo přejato prímo z němčiny, nebo prostřednictvím češtiny.

17 Op. cit. v pozn. 7.

18 Výskyt v Pošumaví lze snadno vysvětlit vlivem poválečného dosidlování obyvatelstvem ze Slovenska; u dokladu z nářečně tradičního Písecka to tak snadné není.

19 Thomas Menzel - Gerd Hentschel (unter Mitarbeit von Pavel Jančák und Jan Balhar), Wörterbuch der deutschen Lehnwörter im Teschener Dialekt des Polnischen, 2., ergänzte und korrigierte elektronische Ausgabe von Studia Slavica Oldenburgensia, Band 10, hrsg. von Rainer Grübel und Gerd Hentschel, Bibliotheks- und Informationssystem der Universität, Oldenburg 2003.

${ }^{20}$ Překvapuje, že autoři slovníku motivaci tohoto významu označují vzhledem k významům předávajícího německého slova za nejasnou. 
(7.7) Čtyři doklady jsou především expresivní povahy. První z nich byl pobaveným ohlasem jednoho čtenáře na autorčinu velmi „,nonkonformní“ básničku o mužích: Evo, Evo, až si to prečte táta, to bude doma rajčur (http://evulka.blog.cz/0604/ basnicka-bez-smyslu - soukromé zápisky) - jde o význam ,mela‘, jímž se nám podrobněji osvětluje vznik významu, nepořádek‘. Podobně název obrazu Karla Jerie „rajčůr 1“ (http://www.galerie-nemecek.cz/1-3.html - stránka internetové galerie Jaroslava Němečka) naznačuje souvislost se zmatkem, neklidem atd. (u uměleckých děl samozřejmě musíme brát obdobná tvrzení s rezervou).

Ve třetím dokladu pak autoři hodnotili promítané filmy stupnicí $1-5$ a pro nejvyšší hodnocení známkou 5 paralelně užili (dle jejich mínění adekvátní) spojení absolutní rajčur (http://home.tiscali.cz/ cz537605/9899_2.html - Marek Burkert, Pavel Doucek, Martin Frank, Pavel Hypius, Jan Jaroš, Program filmového klubu při Filmcentru v Hradci Králové, 1999). V tomto př́ípadě asi jde o významový posun motivovaný nedostatečnou znalostí původního významu slova a jeho kontaminací s expresivním kořenem rajc- (z německého reiz-) s významem ,(pozitivní) vzrušení'. (Stejné spojení ve stejném významu užívá při hodnocení filmů také Daniel Jaroš na stránce Česko-slovenské filmové databáze: http:/www.csfd.cz/uzivatele.php?vice ouzivateli=3509\&zobrazit=komentare a http://www.csfd.cz/film.php?id=9385\&pod le $=$ bodu\&rec $=\&$ top $=\&$ kom $=1 \&$ limk $=-1 \&$ limr $=$ ).

Expresivní povahu má zkoumaný lexém nejspíše také v dokladu V Sobotni kuchařce se Světlanou Lavičkovou jsme vařili Šuprdliky, tedy Polévku vařenou na Rajčúru (http://www.rozhlas.cz/praha/recepty/_zprava/155823 - stránka Českého rozhlasu); z uvedeného receptu není jiná než expresivní motivace názvu pokrmu př́liš patrná. $^{21}$

(7.8) Konečně v posledním zachyceném dokladu autorka, studentka připravující se právě na maturitu, označila daný výraz jako vlastní neologismus (neustále vymýšlím nová slova): demil - nadávka, vzniklá ze slov debil a Emil; humatrální-př́davné jméno od humus; rajčur - vymezený prostor (http://wild-ksilt.blog.cz/0604/muhe he - soukromé zápisky: oddíl je nazván „Nová slova - moje výroba“). Místo o vlastní tvorbu jde $\mathrm{v}$ tomto př́ípadě zřetelně o pasivní znalost některého $\mathrm{z}$ původních významů slova (,ohrada“, ,ohrazené místo“, ,ochoz‘) zasutého v autorčině paměti ...

(8) Zbývá ještě vyrovnat se s dvěma významy ryze slovníkovými. Význam ,dřevěný koník‘ uvedený v Kottově slovníku u výrazu zaznamenaného na Př́borsku koresponduje s významem zachyceným ve slezské němčině ,kolotoč ${ }^{‘}-\mathrm{v}$ obou jde o přenesení pojmenování na hračku. Svědčí o tom i citát dostal krejcar na rajčur (srov. dnešní hovorové metonymické dát dítěti na pouti peníze na koníčky, na autíč$k a$, na labutě apod.). Naproti tomu význam ,angrešt‘ ze Slovníku nespisovné češtiny

${ }^{21}$ Srov. též nápadnou přemíru velkých písmen ... 
jsme ve zkoumaném materiálu nezaznamenali a jeho motivaci považujeme prozatím za nejasnou. ${ }^{22}$

(9) Doklady textů získané prostřednictvím internetu a Českého národního korpusu prokazují, že vedle „oficiálního“ fungování lexikálního systému (nepochybně to však platí též o systému jazyka jako celku) evidovaného (a zpětně fixovaného) jazykovědnými príručkami funguje jakýsi lexikální parasystém, systém druhý, paralelní, systém neřídící se vždy výhradně vývojovými zákonitostmi a ovlivněný více jednotlivými uživateli, jejich individuálními projevy, individuálními vyjadřovacími potřebami a individuálními představami o jazyku. Tento okazionální parasystém jistě neplní základní funkci (celo)národního komunikačního prostředku a vývoj celého lexikálního systému nejspíše ovlivňuje jen okrajově. Přesto není bez užitku si tohoto paralelního jazykového prostředku a jeho fungování všímat, protože dokonce i náhodné procesy, jak víme z matematické teorie, podléhají (třeba dosud nepoznaným) obecným zákonitostem.

\section{$\mathrm{R}$ e s ü m e e}

Die Entwicklung lexikalischer Einheiten in der tschechischen Schrift- und Umgangssprache (am Beispiel von tschechisch rajčúl, rajčúr)

Die fast ausschließlich in der gesprochenen Sprache gebräuchlichen lexikalischen Einheiten waren bis unlängst in den lexikologischen und lexikographischen Arbeiten nur ungenügend untersucht. Dieser Zustand änderte sich grundlegend dank der Entwicklung der technisch unterstützten Korpuslinguistik und des Internets. So scheint z. B. das tschechische Substantiv rajčur (aus dt. Reitschule) lediglich in drei lexikographischen Werken (in Kotts erklärendem Wörterbuch, in Macheks etymologischem Wörterbuch und in Newerklas Wörterbuch der Entlehnungen) sowie im Flurnamen-Index auf, und zwar jeweils unter Angabe verschiedener Quellen und verschiedener Bedeutungen. Das vollständige Bedeutungsspektrum dieses Wortes kann nur dann erfasst werden, wenn wir weiteres Material hinzuziehen: etwa Texte der humanistischen Periode und des Barocks, aber auch Texte aus dem Internet. Auf diese Weise lassen sich neue Erkenntnisse über das lexikalische System gewinnen, auf das peripherisch auch ein lexikalisches Parasystem einwirkt - ein okkasionelles System, das nicht immer mit der regulären Entwicklung konform geht, sondern auch an die individuellen Bedürfnisse der einzelnen Sprecher und ihre Vorstellungen vom Sprachsystem angepasst ist.

Petr Nejedlý

Ústav pro jazyk český AV ČR

Valentinská 1, CZ-116 46 Praha 1

nejedly@ujc.cas.cz

22 Neuvádí jej ani Český jazykový atlas 2 (Balhar, J. - Jančák, P. a kol., Praha 1997, zvl. s. 48-51), který se týká nářečních pojmenování rostlin a zemědělských plodin; můžeme se jen dohadovat, zda nejde o nějakou kontaminaci s pojmenováním rajského jablíčka (viz tamtéž s. 86-88). 